\title{
PERANAN PERPUSTAKAAN KOMUNITAS DALAM MINAT BACA ANAK (STUDI KASUS DI RUMAH BACA ZHAFFA MANGGARAI)
}

\author{
Oleh \\ Hafizal Indra dan Nunung Nurwati
}

\begin{abstract}
ABSTRAK
Peranan yang dilaksanakan Rumah Baca Zhaffa diadaptasi dari peranan perpustakaan komunitas yang tidak lain juga sebagai peran dari perpustakaan. Sebagai tempat penyedia fasilitas pendidikan, menjadikan rumah baca juga dapat menjadi peralihan masyarakat dalam mengakses sumber bahan bacaan dan segala informasi. Adanya rumah baca disekitar masyarakat dapat diharapkan ada pemberian minat kepada masyarakat dan khususnya anak-anak dalam membaca. Peranan perpustakaan dalam rumah baca seperti sebagai tempat pendidikan, penyedia informasi, pengembangan kegiatan positif, dan agen kbudayaan menjadi aspek yang diteliti dalam penelitian ini.

Metode penelitian dengan pendekatan kualitatif dengan teknik penelitian studi kasus, untuk mendapatkan data/Informasi digunakan dengan wawancara mendalam, observasi non-partisipatif, dan studi kepustakaan. Informan yaitu pemilik rumah baca, tokoh masyarakat, dan pengguna rumah baca.

Hasil penelitian ini menunjukkan, perlu dilakukannya upaya untuk meningkatkan publikasi dan kerja sama. Hal ini perlu dilakukan untuk memberikan peningkatan pada rumah baca dalam melaksanakan peranannya. Melihat kurangnya sumber daya dalam hal materil dan manusia, maka rumah baca perlu mendatangkan relawan secara berkala dan mencari donatur atau sponsor tetap dalam hal pendanaan untuk kepentingan peningkatan fasilitas rumah baca.
\end{abstract}

Kata kunci: Peranan, Perpustakaan Komunitas, Rumah Baca

\begin{abstract}
This thesis is a research on the role of a library called Rumah Baca Zhaffa, Manggarai, South Jakarta.The role that Rumah Baca Zhaffa takes part is adapted from the role of community library serves as well as a functioning as a facilitator in education, such literacy shelter functions as well as an alternative in accessing literary and information in general. With the existence of this literacy shelter among the people hopefully it gains interest to read especially for children.The traits of library in literacy shelters that serve the kind of education source, information provider, development of positive acts and cultural agent are the main objectives of this reaearch.

Researcher works with the method of qualitative in combination with case studies. Whereas the instrument used in collecting data is interview as guidance. The technique used is in-depth interview, non-participative observation, and literary study. Informant selected for this research are namely, the owner of literacy shelter, public figure, and two of their returning visitors.

This research shows that it is essential to increase publication and partnership.This is necessary for the reading shelter to continue to serve its roles.Owing to the lack of resources both material and human, therefore this literacy shelter needs regular volunteers and seek for patrons to fund its facilitation upgrade.
\end{abstract}

Keywords: Roles, community library, literacy shelter.

\section{PENDAHULUAN}

Perpustakaan adalah tempat yang memiliki kumpulan buku yang secara terbuka dapat dibaca oleh masyarakat di lingkungan sekitar perpustakaan tersebut. Memiliki tempat sendiri untuk menyimpan buku-buku dan ada orang-orang yang bekerja didalamnya untuk menjaga tempat dan bukubuku yang juga menjadi pengurus dari perpustakaan tersebut. 
Pengertian perpustakaan dilihat dari koleksinya yang masih berbasis kertas adalah kumpulan buku dan materi lainnya yang disimpan untuk bacaan belajar, penelitian, informasi, dan konsultasi. Dalam kaitannya dengan tempat maka definisi sebuah perpustakaan adalah sebuah tempat, gedung, ruangan, atau bagian terbitan lainnya, biasanya disimpan menurut tata susunan tertentu untuk digunakan pembaca. (SulistyoBasuki, 1993:3)

Perpustakaan komunitas adalah seperti hal nya sebuah hasil aksi dari suatu komunitas yang memiliki kesadaraan tentang pendidikan yang kemudian mendirikan sebuah perpustakaan. Pendiri perpustakaan komunitas biasanya tidak menamakan tempat tersebut sebagai suatu "perpustakaan". Sehingga muncul istilah bernama taman baca, rumah baca, rumah belajar, dan pondok baca. Perpustakaan komunitas dapat dimasukkan dalam kategori perpustakaan umum karena sifatnya yang terbuka untuk pengunjung atau pembaca.

Dari data.jakarta.go.id, ada 4 (empat) perpustakaan komunitas pada tahun 2010. Kemudian bertambah 1 (satu) pada tahun 2011 menjadi 4 (empat) perpustakaan komunitas. Pada tahun 2012 dan 2013 tidak ada penambahan jumlah dari tahun 2011 yaitu ada 4 (empat) perpustakaan komunitas.

Rumah Baca Zhaffa adalah salah satu perpustakaan yang berada di Jakarta, tepatnya berada di Jakarta Selatan. Dengan misi menumbuhkan minat baca didalam komunitas wilayah Menara Air dan memiliki langkah selanjutnya untuk membuka rumah baca diwilayah lain. (http://rumahbacazhaffa.blogspot.co.id).

Memberikan fasilitas membaca adalah hal yang terkesan kecil yang dapat dilakukan. Walaupun demikian, membaca memiliki arti yang penting. Menurut Widyamartaya (1992: 140-141), membaca dapat: 1. membuka cakrawala kehidupan bagi pembaca; 2. menyaksikan dunia laindunia renungan dan renungan; 3. merubah pembaca menjadi mempesona dan terasa nikmat tutur katanya. Dalam pernyataannya, menandakan bahwa dengan membaca ada hal yang membuka pikiran yang akan menambah wawasan.

Hasil penelitian yang dilakukan Tim Program of International Student Assessment (PISA), Badan Penelitian dan Pengengembangan Depdiknas menunjukkan kemahiran membaca anak usia 15 tahun di Indonesia sangat memprihatinkan. Sekitar 37,6 persen hanya membaca tanpa menangkap maknanya dan 24,8 persen hanya mengaitkan teks yang dibaca dengan satu informasi (http://edukasi.kompas.com)

Perpustakaan komunitas ini akan memberikan pendidikan bagi mereka yang kurang mandapatkan hak pendidikannya dengan memberikan pelayanan sosial. Muhdi mengartikan bahwa pelayanan sosial mencakup fungsi pengembangan termasuk pelayanan sosial dalam bidang pendidikan, kesehatan, perumahan, dan ketenakakerjaan. (Warto, 2009:11). Sehingga perpustakaan komunitas seperti Rumah Baca Zhaffa juga bukan hanya menjadi wadah tetapi juga dapat memberikan pelayanan sosial bagi anak-anak untuk mendapatkan pendidikan.

Berdasarkan latar belakang yang telah dikemukakan, penelitian ini mengkaji bagaimana peranan perpustakaan komunitas dalam meningkatkan minat baca pada anak.

\section{TINJAUAN KONSEPTUAL}

Dalam setiap hidup dan kehidupannya, manusia mempunyai bermacam peran yang berasal dari perilaku kehidupannya dan hal tersebut menandakan peran menentukan apa yang diperbuatnya bagi masyarakat serta kesempatan apa yang diberikan kepada masyarakat kepadanya dan dengan adanya peran maka tidak akan lepas 
dari status seseorang. Dalam arti tertentu, status dan peran adalah dua aspek dari gejala yang sama. Status merupakan seperangkat hak dan kewajiban, sedangkan peran adalah pemeranan dari perangkat kewajiban dan hak-hak tersebut, berikut beberapa definisi peranan yang dikemukakan oleh beberapa ahli:

Menurut Soerjono Soekanto (1990:24) menyatakan peranan mencakup tiga hal, yaitu:

Peranan meliputi norma-norma yang dihubungkan dengan posisi atau tempat seseorang dalam masyarakat. Peranan dalam arti ini merupakan ringkasan peraturan-peraturan yang membimbing seeorang dalam kehidupan kemasyarakatan.

Peranan adalah suatu konsep tentang apa yang dapat dilakukan oleh individu dalam masyarakat suatu organisasi.

Peranan juga dapat dikatakan sebagai perilaku individu yang penting bagi struktur sosial masyarakat.

Berdasarkan pengertian tersebut dapat dikatakan bahwa peran seseorang dalam masyarakat sangat penting untuk dilaksanakan semaksimal mungkin karena peran tersebut sudah ditujukan kepada setiap orang dari masyarakat dan sudah mendapatkan kepercayaan dari masyarakat itu sendiri. Maka peran adalah suatu harapan yang berfungsi membimbing dan mengatur perilaku seseorang dalam suatu masyarakat dengan bentuk tingkah laku yang sesuai dengan kedudukannya.

\section{Pengertian Perpustakaan Komunitas}

Komunitas berasal dari bahasa Latin, yaitu communis, yang berarti public atau umum, yang harus saling berbagi diantara mereka sendiri. Istilah community dalam bahasa inggris berasal dari bahasa Latin yaitu communtatus, awalan Com- mengandung arti dengan atau bersama. Munis mempunyai arti perubahan atau pertukaran, dan juga dari bahsa Etrucsan yang berarti kemampuan atau berpartisipasi dan akhiran -tatus berarti kecil, intim, atau lokal.

Giggey (1988:11) mendefisikan komunitas sebagai "sekelompok orang yang memiliki kesamaan dalam sesuatu, misalnya usia, pendidikan, agama, minat, organisasi politik, kegiatan, pekerjaan, atau kombinasi dari semua itu". Secara serupa, Usherwood (1991:70) mendefisikan komunitas sebagai "kelompok dari wilayah atau lingkungan mana saja dapat terbentuk menjadi komunitas berdasarkan ras, kelas sosial atau income group, pekerjaan, minat pada waktu luang, agama, dan lain sebagainya, masing-masing dengan jaringan informasi informalnya yang telah berkembang tanpa bantuan pustakawan atau pekerja informasi linnya." Komunitas adalah sekelompok orang yang berada dalam lingkup daerah yang sama atau sekelompok orang yang memiliki hak yang sama atau sekelompok orang yang memiliki tujuan atau minat yang sama (Satpathy, 2007: 20).

Menurut Tropman, Erlich, dan Rothman (2001:37), komunitas dapat dikategorikan berdasarakan:

Letak geografis: mulai dari lingkungan sekitar, pedesaan, kota-kota besar, wilayah, nasional, dan internasional.

Kultur komunikasi: mulai dari clique atau sekelompok kecil orang yang menghabiskan waktu bersama dan tidak membolehkan orang lain bergabung bersama mereka, subkultur, kelompok etnis atau suku, kelompok agama. Multicultural atau kelompok plural, atau komunitas kultur global. Ini termasuk dalam komunitas yang saling membutuhkan atau komunikasi berdasarkan identitasnya.

Organisasi komunitas: mulai dari keluarga secara informal atau yang memiliki hubungan darah samai lembaga 
kontitusi formal, lembaga politik, perusahaan ekonomi, atau lembaga professional tingkat kecil, nasional ataupun internasional.

Menurut Evershed (2005), ciri perpustakaan komunitas yang pertama yaitu melayani masyarakat umum. Tujuannya adalah untuk mengembangkan ilmu pengetahuan dan kemampuan masyarakat umum. Perpustakaan komunitas biasanya didirikan ditengah-tengah masyarakat sehingga mudah untuk diakses oleh masyarakat disekitar tempat perpustakaan komunitas tersebut didirikan. Mostert dan Vermeulen (1998) menyebutkan beberapa karakter perpustakaan komunitas antara lain adalah perpustakaan tersebut dibangun berdasarkan keinginan komunitas dan dikelola dengan partisipasi penuh dan dana dari komunitas tersebut.

\section{Peranan Perpustakaan Komunitas}

Menurut Sutarno (2003:54-55) peran yang harus dijalankan oleh perpustakaan ikut menentukan dan mempengaruhi tercapainya misi dan tujuan perpustakaan. Setiap perpustakaan yang dibangun akan mempunyai makna apabila dapat menjalankan peranannya dengan sebaikbaiknya. Peranan tersebut berhubungan dengan keberadaan, tugas, dan fungsi perpustakaan.

Jika peranan perpustakaan dapat dipenuhi dengan baik, pengguna memperoleh manfaat seperti memelihara dan mengembangkan kemampuan literasi yang didapat, mengakses ilmu pengetahuan sehingga dapat meningkatkan kualitas hidup, mempelajari mengenai isu kesehatan sehingga dapat lebih baik dalam melindungi keluarga dari penakit, menjadi peka terhadap hak-hak demokrasi, meningkatkan kemampuan untuk mendapatkan pekerjaan, menguatkan identitas kebudayaan yang dimiliki, dan mengembangkan kemampuan diri sehigga mampu berpikir kritis (Harrity, 2006:35).

\section{Peranan Perpustaakan Komunitas Sebagai Tempat Pendidikan}

Perpustakaan berperan penting dalam pendidikan seseorang, yaitu untuk membantu menjadikan literasi menjadi sesuatu yang permanen; meningkatkan pengetahuan dan kemampuan yang dimiliki; membantu penyesuaian diri dalam kehidupan bermasyarakat, spiritual, politik, dan ekonomi; memberi tahu hak-hak yang ada dalam bermasyarakat dan untuk menghargai nilai sosial dan siap beradaptasi di masyarakat; dan memungkinkan seseorang untuk mengembangkan kemampuannya secara penuh dan memperluas sudut pandang dan minatnya. (Onohwakpor, 2005)

Untuk memenuhi peran tersebut, perpustakaan umum harus menyediakan sumber-sumber informasi dalam berbagai macam topik yang memungkinkan masyarakat mengembangkan minatnya dan mendukung pendidikan formal dan informalnya.

\section{METODE PENELITIAN}

Penelitian dengan metode deskriptif memberikan gambaran secara mendalam tentang situasi atau proses yang diteliti berupa kata-kata atau lisan dari orang-orang (informan) ataupun perilaku yang dapat diamati sehingga memungkinkan peneliti untuk memahami subjek penelitian. Teknik pengumpulan data menggunakan teknik wawancara kepada pemilik perpustakaan komunitas dan staff perpustakaan komunitas. Informan adalah orang-orang perpustakaan komunitas. Pemilihan informan ini menggunakan teknik purposif yaitu pemilihan informan yang didasarkan pada kebutuhan tujuan, fungsi, dan kegunaan data. 


\section{PEMBAHASAN}

Rumah Baca Zhaffa (RBZ) adalah perpustakaan yang didirikan untuk memberikan fasilitas membaca untuk masyarakat di sekitar Kelurahan Manggarai. Rumah Baca Zhaffa didirikan oleh beberapa orang di Kelurahan Manggarai yang juga tergabung menjadi anggota Karang Taruna Manggarai, dengan Yudi sebagai penggagas. Para pendiri Rumah Baca Zhaffa tersebut memiliki niat ingin melakukan sesuatu untuk membantu anak-anak dan remaja terutama mengenai pendidikan dan kurangnya akses mendapatkan buku bacaan di lingkungan tersebut. Rumah Baca Zhaffa berdiri pada tanggal 24 Agustus 2008 yang diharapkan oleh pada pendirinya untuk menjadi sarana anak-anak dan remaja untuk mengisi hariharinya dengan kegiatan yang positif. Namun rencana untuk mendirikan sebuah rumah baca telah ada dari tahun 2006. Perlu dua tahun untuk terbentuknya rumah baca ini karena permasalahan tempat untuk mendirikannya.

Rumah Baca Zhaffa didirikan untuk menutup adanya kekurangan dalam penerimaan hak dimasyarakat yaitu hak menerima pendidikan. Bukan hanya pendidikan yang layak namun juga pendidikan yang berkualitas. Memberikan akses tersebut kepada masyarakat menjadi hal utama bagi Rumah Baca Zhaffa. Namun bukan hanya untuk masyarakat yang dari kalangan sulit atau miskin tetapi juga terbuka bagi semua kalangan dan golongan dan untuk berbagai usia dari anak hingga dewasa.

Fasilitas Rumah Baca Zhaffa tidak terbilang telah lengkap seperti perpustakaan umum kota. Secara bentuk fisik memang tidak seperti perpustakaan pada umumnya. Namun untuk memberikan ruang dalam memberikan kegiatan belajar dan membaca, sudah cukup untuk hal tersebut. Dengan adanya renovasi, Rumah Baca Zhaffa memiliki ruang tambahan untuk melakukan kegiatan.

Buku yang dipinjam dapat juga berupa jenis buku apapun yang ada di Rumah Baca Zhaffa. Jika ingin meminjam buku, maka perlu menulis sendiri dibuku catatan peminjaman buku, judul buku, tanggal peminjaman, dan nama peminjam. Peminjaman buku ini tidak dikenakan biaya apapun atau gratis untuk meminjam buku. Model peminjaman yang gratis dan tidak menyulitkan pembaca untuk meminjam ini dimaksudkan untuk memberikan kepercayaan kepada masyarakat. Karena tidak ada jaminan dalam meminjam buku, maka rumah baca menganggap seseorang yang meminjam buku dapat dipercaya akan mengembalikan buku tersebut dan dalam keadaan yang baik. Layanan Rumah Baca Zhaffa dimulai pukul 16.00 hingga 20.00 untuk.

Pendidikan yang ditawarkan oleh Rumah Baca Zhaffa tidak hanya bermodalkan buku atau pun memberikan model self service atau membuat anak membaca sendiri buku yang dibaca dan membiarkannya belajar sendiri. Tetapi dengan menekankan model bermain sambil belajar dapat memacu anak untuk meningkatkan daya tangkap mereka untuk belajar dan mendapatkan ilmu yang baru karena itu memang tujuan didirikannya rumah baca dengan yang sesuai diungkapkan:

"Mendirikan Rumah Baca Zhaffa ini supaya anak-anak dapat akses buku. Jadi di rumah baca ini semua orang bisa baca buku gratis. Ngga dipungut biaya." (YD, 14 November 2016).

Rumah Baca Zhaffa memiliki pembimbing yang secara sukarela menawarkan diri untuk berjasa sebagai pembimbing belajar. Bimbingan yang 
ditawarkan tidak sepenuhnya seperti halnya belajar disekolah.

Untuk memberikan pelayanan pendidikan, Rumah Baca Zhaffa menekankan bahwa rumah baca adalah tempat menempuh pendidikan secara nonformal. Sehingga untuk memberikan pengetahuan atau memberikan pendidikan pada anak, maka tidak terpacu pada model yang ada disekolah.

Pelajaran yang diutamakan untuk anak-anak ketika usia sekolah tentu pelajaran-pelajaran atau pun pendidikan seperti yang diberikan disekolah. Seperti pelajaran-pelajaran matematika, bahasa, ilmu pengetahuan alam, dan ilmu pengetahuan sosial. Itu lah pelajaran-pelajaran utama yang menjadi pokok penting dalam pendidikan. Rumah Baca Zhaffa memberikan pelajaranpelajaran tersebut kepada anak-anak yang ingin mengikuti kegiatan bimbingan belajar yang diberikan oleh Rumah Baca Zhaffa. Dengan relawan-relawan yang membantu Rumah Baca Zhaffa dalam melaksanakan kegiatan bimbingan belajar, pelajaranpelajaran sekolah dapat diberikan kepada anak-anak di lingkungan menara air dan tentu juga di lingkungan Kelurahan Manggarai.

Pelajaran sesuai dengan yang sedang dipelajari anak-anak disekolah. Pengajar akan memberikan pelajaran yang seperti dikelas. Anak-anak hanya akan mengulang pelajaran-pelajaran yang ada disekolah. Hal ini dimaksudkan untuk anak dapat belajar suatu hal dengan baik karena pembelajaran telah diulang atau dipelajari kembali. Hal ini juga dimaksudkan untuk anak yang belum mengerti ketika belajar disekolah. Sehingga anak dapat memahaminya ketika mengulang pelajaran di Rumah Baca Zhaffa seperti yang dikatakan pemilik rumah baca:

"Yang dibutuhkan anak-anak. Kaya yang disekolah cuma ga terlalu kaku. Jadi anak-anak belajarnya ga capenya aja tapi seneng juga." (YD, 14 November 2016).
Menyesuaikan dengan pelajaran disekolah, anak dapat meminta kepada relawan pengajar untuk meteri pembelajaran yang ingin dipelajari. Namun permintaan hal seperti itu tidak dapat langsung dipenuhi karena pengajar pun perlu belajar terlebih dahulu tentang materi yang anak ingin pelajari. Kecuali jika pengajar memang ahli dalam hal yang anak minta. Maka pembelajaran tentang materi yang diminta anak dapat langsung diberikan oleh pengajar. "Belajar biasa ada. Bahasa Indonesia, bahasa inggris, matematika." (AR, 11 Januari 2017).

Ketika pada waktu ujian nasional, Rumah Baca Zhaffa akan memberikan pelajaran yang berkaitan dengan ujian nasional. Seperti matematika, bahasa Indonesia, bahasa inggris, ilmu pengetahuan alam, dan ilmu pengetahuan sosial. Kelas yang dibuka oleh Rumah Baca Zhaffa ialah kelas 6 SD dan juga 3 SMP yang akan mengikuti ujian nasional. Pelajaran-pelajaran yang ada di ujian nasional akan dikhususkan untuk anak-anak yang akan ujian nasional. Kemudian jadwal untuk belajar pun ditentukan, supaya adanya kedisiplinan bagi anak untuk belajar.

\section{SIMPULAN}

Manfaat adanya Rumah Baca Zhaffa dirasakan langsung oleh masyarakat sekitar. Manfaat yang diperoleh dengan adanya Rumah Baca Zhaffa yaitu anak-anak memiliki lebih banyak waktu yang bermanfaat karena dapat membaca, belajar sambil bermain, dan beraktivitas dengan kegiatan yang ada di Rumah Baca Zhaffa dan diadakan oleh Rumah Baca Zhaffa.

Masyarakat dapat mengakses bukubuku tersebut di Rumah Baca Zhaffa tanpa dipungut biaya apapun. Rumah Baca Zhaffa berperan sebagai tempat pendidikan dengan 
menyediakan bimbingan belajar yang ditujukan untuk anak mulai dari sekolah dasar hingga sekolah menengah pertama.

Rumah Baca Zhaffa mengadakan bimbingan belajar yang terbuka untuk umum yang disesuaikan dengan kelasnya dan gratis bagi anak-anak yang ingin mengikutinya.

\section{DAFTAR PUSTAKA}

Evershed, Jane. 2005. Community-based library.

Gigey, S. 1998. Rural Community Resources: a guide for developing countries. London: Mac Millan.

Harrity, Sarra. 2006. Creating literate environments: the Role of Libraries. Book Aid International. London: Commonwealth Foundation.

Onohwakpor, J. E. 2005. The Role of Library Services in Adult Literacy Education. Library Philosophy and Practice, vol. 7.

Sutarno. 2003. Perpustakaan dan Masyarakat. Jakarta: Yayasan Obor Indonesia

rumahbaca-zhaffa.blogspot.co.id.
Soerjano, Soekanto. 1990. Sosiologi Suatu Pengantar. Jakarta: Raja Grafindo Persada

Sulistyo-Basuki. 1993. Pengantar Ilmu Perpustakaan. Jakarta: Gramedia. Pere Rise and Growth of NGOs and Communities Sponsored Public Libraries in Indonesia's post President Soeharto, an Instant Phenomena.

Usherwood, B. 1991. The Neighbourhood Information Network. DESIDOC Bulletin of Information Technology, vol. 19.

Warto. 2009. Efektivitas Program Pelayanan Sosial di Panti dan Non Panti Rehabilitasi Korban Napza. Yogyakarta: B2P3KS Press.

Widyamartaya, A. 1992. Seni Membaca Untuk Studi. Yogyakarta: Kanisius.

$\underline{\text { http://data.jakarta.go.id/dataset/jumlahperpu }}$ stakaan-koleksi-anggotapengunjungdanpetugasdkijakarta/res ource/6d68df9f-33b3-438a-bcf337d6692c55ba. 